\title{
Irmandades, oficiais mecânicos e cidadania no Rio de Janeiro do século XVIII
}

\section{Brotherhood, artisans and citizenship in Eighteenth century Rio de Janeiro**}

\author{
BEATRIZ CATÃo CRUZ SANTOS \\ Doutora pela Universidade Federal Fluminense \\ Professora de História da Universidade Federal do Rio de Janeiro \\ Instituto de Filosofia e Ciências Sociais - (IFCS) \\ Largo São Francisco de Paula, $n^{\circ} 1$, Centro \\ Cep: $20.290-240$ \\ biacatao@openlink.com.br
}

RESUMO O artigo propõe uma reflexão sobre os meios de inserção dos ofícios na comunidade política do Rio de Janeiro no século XVIII. Para tanto, focaliza as irmandades de ofícios, consideradas como formas de socialização que tem como referência a igreja católica e a monarquia. Nelas, o domínio de um ofício constituía um critério de ingresso, fossem os irmãos livres, libertos ou escravos. Analisam-se particularmente os casos da irmandade de São Jorge - que reunia basicamente os ofícios do ferro e do fogo - e da irmandade de São José - que congregava carpinteiros, pedreiros e marceneiros. Em termos gerais, objetiva-se investigar a natureza e as condições da cidadania dos ofícios em uma sociedade do Antigo

* $\quad$ Artigo recebido em: 14/11/2008. Aprovado em: 19/06/2009.

** O presente trabalho foi realizado com o apoio da Fundação Biblioteca Nacional (BN). 
Regime português, a partir das relações entre as irmandades, os oficiais mecânicos e o Senado da câmara.

Palavras-chave cidadania, irmandades, bem comum

ABSTRACT The article suggests a reflection on the insertion means of the artisans in the Rio de Janeiro political community, during the 18th century. For this purpose it focus the artisan's brotherhoods, considered as a socialization forms, that has as reference the catholic church and the monarchy. The expertise in the trade was a criterion for the admission, be the brothers free, freed men or slaves. In particular, are analyzed the cases of Saint George's brotherhood - that joined together basically the iron and fire trades - and Saint Joseph's brotherhood - that brought together carpenters, masons and joiners. In general terms, the objective is to investigate the nature and the conditions of citizenship of the trades in a society of the old Portuguese regime, from the relations between the brotherhoods, the craftsmen and the municipal council.

Keywords citizenship, brotherhood, welfare

É complexa a aplicação do conceito de cidadania para o período do Antigo Regime. O seu sentido é diverso da compreensão atual e está associado a uma dada idéia de naturalidade, confundindo-se com a noção de vizinhança. Hoje, ao fazermos uso do conceito, apontamos para um conjunto de direitos (e deveres), que inclui a participação política. Naquele período, que, grosso modo, se estende até a Revolução Francesa, cidadania significava uma naturalidade comum. No mundo português, era atribuída por nascimento, concessão régia ou direito consuetudinário ("viver limpamente e à lei da nobreza", exercer cargos que só se costumam atribuir a gente nobre). Cidadania também se confundia com a noção de vizinhança, no sentido de estar radicado, morar e exercer cargos, principalmente nas câmaras municipais. ${ }^{1}$ Estes significados foram apreendidos por Araújo Lima na Constituinte de 1823 ao comentar que,

a palavra Cidadão não induz igualdade de direitos (...). Na língua Portuguesa donde derivamos a nossa, bem como na Espanhola, a palavra Cidadão tem uma

1 HESPANHA, António Manuel. Porque é que foi "portuguesa" a expansão portuguesa? ou O revisionismo nos trópicos. In: BICALHO, Maria Fernanda; FURTADO, Junia Ferreira; SOUZA, Laura de Mello (orgs.) O governo dos Povos. São Paulo: Alameda, 2009, p.52-55; BICALHO, Maria Fernanda. O que significava ser cidadão nos tempos coloniais? In: ABREU, Martha e SOHIET, Rachel. (orgs.) Ensino de História. Rio de Janeiro: Casa da Palavra, 2003. 
significação muito particular, ela designava o morador ou o vizinho da Cidade. Sabe-se que pelo Direito Feudal as povoações, segundo que eram Cidades, Vilas ou lugares, tinham assim diferentes direitos, gozavam certos privilégios, liberdades e isenções. Isto era muito importante naquele tempo; e a palavra Cidadão designava como já disse, o morador ou o vizinho da Cidade, o qual por isso gozava diferentes direitos que não se estendiam a todos os Membros da sociedade: e é daí que veio o direito de vizinhança; isto porém acabou, e por tanto deve ser extensa esta denominação a todos os indivíduos. ${ }^{2}$

O discurso deve ser interpretado no contexto de um país que adquiria há pouco a independência política e do Parlamento, que se constituía num dos espaços de invenção do cidadão e, simultaneamente, do brasileiro. Considerando as opiniões e direções políticas impressas por Araújo Lima, ${ }^{3}$ interessa sublinhar que a idéia de cidadão dos tempos idos, leia-se, da sociedade colonial, implicava desigualdade, confundia-se com o morador ou vizinho da cidade e não incluía o conjunto dos habitantes da cidade e seu termo. Ademais, faz lembrar que alguns cidadãos, como fora o caso dos cidadãos de Lisboa, Évora e Porto foram agraciados com privilégios pelos reis de Portugal por suas demonstrações de lealdade e fidelidade. Em 1642, os cidadãos do Rio de Janeiro receberiam de dom João IV os mesmos privilégios, honras e liberdades conferidas por dom João Il à cidade do Porto, que, como observou Fernanda Bicalho, distinguiam a nobreza do povo miúdo. ${ }^{4}$

Os significados em movimento do termo cidadão no Brasil entre os séculos XVIII e XIX tem sido alvo de análises pontuais. Se bem que Hebe Mattos, no livro Escravidão e cidadania no Brasil monárquico, desenvolve uma perspectiva abrangente sobre o tema da cidadania no Brasil oitocentista e indica como o conceito de raça foi coetâneo e correlato à discussão dos direitos civis e políticos inerentes à cidadania dos novos Estados liberais nas Américas. A partir de uma abordagem comparativa entre o Brasil e os Estados Unidos da América, procura demonstrar o quanto a questão da manutenção da escravidão na emergência da ordem liberal se complexifica no Brasil, que detém na passagem do século XVIII para o XX a terceira maior população de escravos da América e a maior população de afrodescendentes livres. Nesse contexto, a autora sinaliza com acuidade para

2 Diário da Assembléia Geral, Constituinte e Legislativa. v.2, n.9, p.106 (grifos meus).

3 Pedro Araújo Lima (1793- 1870) era membro da aristocracia rural pernambucana. Formou-se em Direito na Universidade de Coimbra, tendo logo exercido a magistratura. Foi eleito deputado para as Cortes de Lisboa, para a Constituinte de 1823 e para as três legislaturas subseqüentes. Em 1837, foi nomeado senador pela Regência, ministro do Império e, em seguida (com a renúncia de Feijó), regente uno. Em 1841 recebeu o título de visconde de Olinda e, em 1854, o de marquês de Olinda, já tendo sido antes condecorado com a grã-cruz da Ordem de Cristo e com o oficialato da Ordem do Cruzeiro. Foi também sócio-fundador do Instituto Histórico e Geográfico Brasileiro. Sua trajetória política foi evidentemente relevante e marcada por tendências conservadoras. Apoiou o governo de Pedro I, filiou-se aos caramurus após a Abdicação, depois foi um dos líderes do Regresso e, por fim, aderiu ao Partido Conservador. Agradeço estas informações biográficas a Marcello Basile.

4 BICALHO, Maria Fernanda. O que significava ser cidadão nos tempos coloniais?, p.145. 
a emergência da categoria "pardo", condição lingüística necessária para expressar o crescimento contínuo de uma população livre de ascendência africana, sobre a qual não recaía "o estigma da escravidão, mas sem que se perdesse a memória dela e das restrições civis que implicava". ${ }^{5}$

No trabalho de Tamar Herzog, ${ }^{6}$ encontra-se uma tentativa de sistematizar a questão das mudanças da cidadania na Espanha e na América espanhola. Em termos gerais, ela aponta para o surgimento de um regime de cidadania comum no mundo hispânico no início da época moderna. A partir da descrição da categoria de "nativo" (natural) primeiro de Castela, e depois de Espanha, e da relação entre naturalidade e cidadania local (vecindad) sinaliza para as mudanças destas noções, com ênfase na passagem para a condição de Estado, efetuada no século XIX. Para Herzog, a moderna cidadania nacional na Espanha e na América espanhola advém da cidadania local - eram os "cidadãos dos lugares" -, que por um processo de extensão e empréstimo deixaria marcas até o século XX. O trabalho cobre regiões diversas, tem sido bastante referido pela historiografia portuguesa e já serviu à discussões assemelhadas para o Peru, entre fins do Vice-Reinado e as primeiras décadas da República. ${ }^{7}$

A partir destas referências, pode-se dizer que cidadania na sociedade colonial da América portuguesa aponta prioritariamente para a relação entre o indivíduo e a comunidade local. Como decorrência, para o pertencimento ou não ao reino português. Neste sentido, vale observar que em Portugal é justamente entre meados do século XVIII e meados do XIX que se assiste uma valorização do conceito de cidadão simultânea a uma depreciação política do conceito de vizinho, confinado por fim à esfera da vida local e depois à vida privada. ${ }^{8} \mathrm{Na}$ América portuguesa, não há evidencias suficientes para indicar este contraste. Tenho por objetivo contribuir para uma definição de cidadania, que transcende o exercício de cargos na administração sem deixar de reconhecer o senado da câmara como a via principal para o acesso ao estatuto de cidadão, inclusive como espaço de nobilitação, hierarquização dos colonos e participação no governo político do império. ${ }^{9}$ A intenção é extrair das práticas sociais uma definição mais geral e precisa, que leve em conta as categorias de cidadão, natural e vizinho, e, ao mesmo tempo, reconhecer outros agentes e instituições em jogo.

Há poucos trabalhos da historiografia sobre a cidadania no período colonial, em particular, dos oficiais mecânicos. Este texto pretende justa-

5 MATTOS, Hebe Maria. Escravidão e cidadania no Brasil monárquico. Rio de Janeiro: Zahar, 2000, p.17.

6 HERZOG, Tamar. Defining nations: immigrants and citizens in early modern Spain and Spanish America. Yale: Yale University, 2003.

7 NÚÑEZ, Francisco. Vecino-ciudadano (Péru 1750-1850). Revista Araucária, Sevilha, n.7, ano 9, primeiro semestre de 2007

8 RAMOS, Rui. Vecino/Ciudadano (Portugal). In: SEBASTIÁN, Javier Fernández. (org.) Diccionario político y social del mundo iberoamericano. Conceptos políticos en la era de las revoluciones, 1750-1850. Madrid, CEPC, 2009.

9 BICALHO, Maria Fernanda. O que significava ser cidadão nos tempos coloniais?, p.145. 
mente refletir sobre a natureza e condições da cidadania daqueles grupos no Rio de Janeiro do século XVIII. Com esta finalidade, levarei em conta a produção historiográfica que dá ênfase à noção de império e efetua uma reflexão sobre o espaço português transatlântico; tomando primeiramente (1) os trabalhos pioneiros sobre a cidadania e sobre os ofícios na América portuguesa, em segundo lugar (2) aqueles produzidos pela historiografia desde fins dos anos 1980 até hoje; e, para efeito de comparação, (3) as investigações sobre as noções de cidadania, naturalidade e vizinhança no Império espanhol. ${ }^{10} \mathrm{~A}$ classificação apresentada implica interseções, serve apenas para arrumar o debate historiográfico e tem em vista a análise de alguns documentos, por meio dos quais, reconstrói-se a experiência dos artesãos. Dar-se-á destaque também às idéias de "bom governo" e de "bom regime", recorrente na documentação das irmandades, senado da câmara e outros agentes da Coroa portuguesa. Nesses textos, esta noção parece remeter a um sentido de justiça comum, cuja formulação aponta para a centralidade da noção de equidade. Segundo Giovanni Levi, ${ }^{11}$ nas nações católicas do mediterrâneo, ou seja, naquelas em que não se efetuara uma nítida separação e hierarquização do Estado em relação à igreja, havia não só uma fragilidade da ordem estatal, mas um sentido de justiça comum de origem teológica, que dava ampla margem de interpretação aos juízes e também informava outras práticas sociais e culturais. Estas características identificadas na Europa mediterrânea podem ser aplicadas à interpretação daqueles agentes e instituições da América portuguesa.

Assim, para refletir sobre a cidadania no período colonial, coloco o foco nas irmandades de ofícios, suas relações com os ofícios mecânicos e a câmara, por intermédio do juiz de ofício e da Casa dos Vinte e Quatro. Neste texto, as irmandades de ofíciosão consideradas formas de socialização que tem como referência a igreja católica e a monarquia e em que o domínio de um ofício constituía um critério de ingresso, fossem os irmãos livres, libertos ou escravos. Como a pesquisa está em andamento, analiso

10 A seguir listo os trabalhos, conforme os grupos indicados: (1) HESPANHA, António Manuel. Porque é que foi "portuguesa" a expansão portuguesa? ou O revisionismo nos trópicos, p.52-55; FRAGOSO, João; GOUVÊA, Maria de Fátima e BICALHO, Maria Fernanda. Bases da Materialidade e da Governabilidade no Império: uma leitura do Brasil Colonial. Penélope, v.23, 2000; (2) BICALHO, Maria Fernanda. O que significava ser cidadão nos tempos coloniais?; MATTOS, Hebe Maria. Escravidão e cidadania no Brasil monárquico; RIOS, Wilson de Oliveira. A Lei e o Estilo. A inserção dos ofícios mecânicos na sociedade colonial.1690-1790. Niterói: UFF, 2000 (História, Tese de doutorado); MARTINS, Monica de Souza Nunes. Entre a cruz e o capital: mestres, aprendizes e corporações de ofícios no Rio de Janeiro (1808-1824). Rio de Janeiro: IFCS/UFRJ, 2007; MENESES, José Newton Coelho. Mestres do reino, mecânicos do além-mar. A organização do trabalho mecânico em Lisboa e nas Minas Gerais portuguesas dos setecentos. In: PAIVA, Eduardo França. (org.) Brasil-Portugal: sociedades, culturas e formas de governar no mundo português (séculos XVI-XVIII). São Paulo: Annablume, 2006; SANTOS, Beatriz Catão Cruz e FERREIRA, Bernardo. Vecino/Ciudadano (Brasil). In: SEBASTIÁN, Javier Fernández. (org.) Diccionario político y social del mundo iberoamericano; SANTOS, Beatriz Catão Cruz e FERREIRA, Bernardo. Cidadão/Vizinho. Ler Historia, Dossier: História conceptual no mundo luso-brasileiro. 1750-1850, n.55, p.35-48, 2008; (3) HERZOG, Tamar. Defining nations; NúÑEZ, Francisco. Vecino-ciudadano (Péru 1750-1850).

11 LEVI, Giovanni. Reciprocidad mediterránea. Tiempos Modernos: Revista Electrónica de Historia Moderna, n.7, v.3, 2002 http://www.tiemposmodernos.org/viewissue.php?id=7 (Consultado em 4/06/2007). 
particularmente duas irmandades - São Jorge e São José - identificando seus integrantes e suas formas de inserção na comunidade política do Rio de Janeiro do século XVIII.

Neste ponto, vale recordar brevemente que a história das irmandades na América portuguesa começa no reino, se mistura com a história das corporações de ofício e remonta à Idade Média. ${ }^{12}$ É necessário recuperar o assunto em busca de uma abordagem que relacione ofícios e irmandades. De maneira geral, os autores que tratam do tema reconhecem que as irmandades surgiram nos séculos $\mathrm{X}$ e XI, associadas ao desenvolvimento das cidades e das atividades artesanais e comerciais. Em Portugal, as primeiras associações seriam as de ofícios, resultantes de profissionais domiciliados e estabelecidos numa mesma rua, sendo suas finalidades de caráter mutualista. Nessa perspectiva, as irmandades leigas em Portugal "tiveram a permeá-las e a precedê-las os hospitais e os ofícios, dos quais foram a face religiosa". ${ }^{13}$ Não à toa, no conjunto do continente europeu a igreja teria passado de uma posição de hostilidade em relação às corporações para um posterior controle, inclusive pela submissão delas ao direito canônico e as normas do "bem comum". ${ }^{14}$ Se no reino as corporações de ofício precedem as irmandades propriamente ditas, no Rio de Janeiro colonial elas aparecem entrelaçadasàs irmandades.

Desde a interpretação de Charles H. Boxer, de 1969, ${ }^{15}$ que apontava para o desenvolvimento das irmandades particularmente na época da expansão marítima e seu papel na constituição da unidade do Império português, a historiografia muito produziu sobre o assunto. Sem deixar de reconhecer esta bibliografia, proposições lançadas por Caio Boschi, recuperadas posteriormente, ${ }^{16}$ podem auxiliar na definição das suas funções na sociedade colonial e suas relações com a igreja e a monarquia portuguesa. As irmandades, segundo o autor, constituíam forças auxiliares do Estado português e, simultaneamente, expressão orgânica e local. Apesar de separar estado/igreja, Caio Boschi apreendeu com acuidade o papel contraditório das irmandades, que se organizavam a partir das estruturas administrativas da monarquia, mas que respondiam aos interesses de diversos grupos sociais - no caso, dos oficiais mecânicos - inscritos nas localidades.

12 GONÇALVES, Lopes. As corporações e as bandeiras de ofícios. Revista do Instituto Histórico e Geográfico Brasileiro, Rio de Janeiro. v.206, p.171-191, 1952; BOSCHI, Caio César. Os leigos e o poder: irmandades leigas e política colonizadora em Minas Gerais. São Paulo: Ática, 1986, p.36-70; BASCHET, Jérome. A civilização feudal. Rio de Janeiro: Globo, 2006.

$13 \mathrm{BOSCH}$, Caio César. Os leigos e o poder, p.51, 53.

14 LE GOFF, Jacques. Para um novo conceito de idade média: tempo, trabalho e cultura no ocidente. Lisboa: Estampa, 1980, p.155-156.

15 BOXER, Charles H. O império marítimo português.

16 MARTINS, Monica de Souza Nunes. Entre a cruz e o capital: as corporações de ofícios no Rio de Janeiro após a chegada da família real (1808-1824). Rio de Janeiro: Garamond, 2008. 


\section{As irmandades de São Jorge e de São José no Rio de Janeiro}

A irmandade do Glorioso Mártir São Jorge surge por volta de 1740 e sua capela situava-se na igreja de Nossa Senhora do Parto, como hoje, na rua da Assembléia. Era um templo aberto à presença de africanos desde a sua fundação. ${ }^{17}$ Como inúmeras outras dessas associações na sociedade colonial, seu primeiro compromisso viria apenas em 1757, para evitar "entre os irmãos certas desordens". ${ }^{18}$ A irmandade do Bem Aventurado Patriarcha de São José é de cerca de 1608 - está entre as mais antigas da cidade mas, darei prioridade a sua história durante o século XVIII. Localizava-se de frente para a cadeia, no quarteirão entre as ruas de São José e hoje, da Assembléia. ${ }^{19}$ Portanto, no passado, as duas irmandades eram vizinhas.

Segundo o compromisso de São Jorge, de 1757, eram "obrigados a ser irmãos nesta Irmandade todos os Mestres que tiverem loja aberta dos ofícios anexos a mesma Irmandade, ou seja, os de Serralheiro, Ferreiro, Cuteleiro, Espingardeiro, Latoeiro, Funileiro, Caldeireiro, Ferrador, Espadeiro, Dourador e Barbeiro e todos os mais ofícios que na corte costumam pagar para a confraria deste Glorioso Santo". ${ }^{20}$ Em 1791, novo compromisso é elaborado e, a julgar pelo documento aprovado, sua instituição tem por finalidade "o bom regime da Referida Irmandade". Por intermédio da análise dos dois estatutos e demais documentos anexos ao processo de aprovação, sabe-se que foram incluídos os picheleiros, seleiros e tanoeiros. ${ }^{21}$ Como na irmandade lisboeta, eram ofícios do ferro e/ou do fogo mas, à diferença daquela, estava aberta a mulheres, cativos e forros e, em 1791, incorpora outros tipos de ofícios. ${ }^{22}$

A composição social dos membros da irmandade de São Jorge merece uma análise pormenorizada. Como fica insinuado na citação, havia um nexo compulsório entre o exercício dos ofícios do ferro e fogo e a irmandade de São Jorge. Para se tornar um oficial e/ou mestre e manter a posição, faziase necessário cumprir uma série de regras: ingressar na irmandade, obter

17 Em texto anterior forneço dados detalhados sobre a Igreja de Nossa Senhora do Parto, onde a irmandade surgiu. SANTOS, Beatriz Catão Cruz. The feast of Corpus Christi: artisan crafts and skilled trades in Eitheenth-century Rio de Janeiro. The Americas, v.65, n.2, p.163-216, 2008

18 Lisboa. Arquivo Histórico Ultramarino (AHU). Códice 1949, CD-room 25. Compromisso da Irmandade do Glorioso São Jorge no Rio de Janeiro (1757).

191608 é a data da ermida, mas há indicações sobre a construção da Igreja, que abrigaria a irmandade São José de 1681. FAZENDA, Vieira. As bandeiras dos ofícios; São José. Revista do Instituto Histórico e Geográfico Brasileiro, Rio de Janeiro, t.86, v.140, p.131-135, 1919; GERSON, Brasil. História das ruas do Rio. 5.ed. Rio de Janeiro: Lacerda, 2000, p.5-9; ROHAN, Amadeu de Beaurepaire. Memória histórica da Igreja e da Irmandade de S. José. Rio de Janeiro: Tipografia do Jornal do Comércio, 1823, p.15-22. Há uma certa polêmica quanto à localização da irmandade, mas a hipótese de Vieira Fazenda e de outros que o seguiram sugere que o templo já ocupava o local da igreja atual.

20 AHU, Códice 1949, CD-room 25. Compromisso da Irmandade do Glorioso São Jorge no Rio de Janeiro (1757).

21 AHU, Códice 1952, CD-room 25. Compromisso (acrescentamentos dos capítulos) da Irmandade do Glorioso Mártir São Jorge no Rio de Janeiro (1791). Tanoeiro era aquele que fazia ou consertava tonéis, pipas ou barris; picheleiro, o que fazia vasos de estanho, e de lata de flandres e o seleiro, selas para animais.

22 Para informações sobre a Irmandade de Lisboa, ver SANTOS, Georgina Silva dos. Ofício e Sangue: tempo, trabalho e cultura no ocidente. Lisboa: Colibri, 2005 e sobre a do Rio de Janeiro ver SANTOS, Beatriz Catão Cruz. The feast of Corpus Christi: artisan crafts and skilled trades in Eitheenth-century. 
licença para exercer o ofício e efetuar pagamentos (entradas, anuais, taxas de exame). ${ }^{23}$ Para além das diferenças relativas à congênere lisboeta, 0 primeiro compromisso vedava o acesso de "Judeu, Mouro, negro ou mulato ou de outra infecta nação", atualizando os critérios de limpeza de sangue. No entanto, durante o processo de aprovação, alguns de seus capítulos foram alvos de polêmica pela administração central e local. No final, por intermédio do Conselho Ultramarino, o rei exigiu a revogação de alguns estatutos propostos pelos irmãos de São Jorge para garantir sua confirmação. Segundo o parecer do conselheiro Alexandre de Mello e Souza e Menezes não caberia à irmandade ter a "jurisdição para tirar inquirição e infamar famílias", ${ }^{24}$ retirando tão somente da letra da lei o preconceito racial. O fato é que o próprio compromisso admite a existência de irmãos proprietários de escravos e de irmãos forros e cativos, que se integram à irmandade pelo domínio do ofício. Por seu status diferenciado, estes últimos seriam irmãos de menor condição, o que não Ihes eximia nem de pagamento, nem de exame. Em outras palavras, pagavam um valor menor de entrada e recebiam menos privilégios. A regra social da equidade determinava: dar a cada um, conforme o seu status. ${ }^{25} \mathrm{O}$ ingresso dos tanoeiros foi uma das razões para a elaboração de um novo compromisso. E, neste ponto, vale destacar as justificativas apresentadas pelos irmãos de São Jorge para aceitá-los, as mudanças operadas no regulamento e a reciprocidade implícita entre os primeiros e os novos, que passam a estar "sujeitos a todos os encargos dela [irmandade], e gozarão de todos os privilégios, e graças e isenções". 26 Como se evidencia na leitura do conjunto documental, os irmãos de São Jorge incorporavam os tanoeiros e viriam a aceitar outros ofícios, por estarem em falta de irmãos, por sua pobreza e pela despesa com a capela de São Jorge em construção. ${ }^{27}$ Note-se que a necessidade de irmãos e suas

23 O termo licença é usado no corpo do texto de forma genérica, como permissão. No entanto, na documentação encontram-se carta de exame e licença. A carta é o documento concedido pelo juiz e escrivão do ofício para o mestre exercer a sua profissão na cidade. Ela é dada àquele que pagou as taxas (entrada na irmandade, taxa de exame), foi examinado (pelo juiz ou por um avaliador escolhido), realizou juramento sobre os Evangelhos e obteve confirmação da sua carta de exame no Senado da Câmara. Esta confirmação é também denominada licença. Como o é a licença provisória expedida pelo Senado da Câmara, sem o processo anterior preconizado pelas irmandades.

24 AHU. Códice 1949, CD-room 25. Compromisso da Irmandade do Glorioso São Jorge no Rio de Janeiro (1757).

25 De acordo com o compromisso (1757) todos os irmãos deveriam pagar de entrada 1926 réis, de anual 640 réis, mas juiz, escrivão, tesoureiro e procurador contribuíam também com uma esmola, que decresce conforme a importância do cargo (2000, 1600 e 1280 reis para os dois últimos). É importante destacar que "os de sangue impuro" que trabalharem no ofício com loja aberta deverão pagar o mesmo anual de todos os irmãos e o "oficial jornaleiro", que pode ser livre ou cativo, deverá pagar um valor menor a todos os demais, de 480 reis. No primeiro caso, quanto no segundo, mais expressivo, teriam acesso somente à sepultura. Compromisso da Irmandade do Glorioso São Jorge no Rio de Janeiro (1757). Capítulos 4, 5, 6,7, 10. Para a noção de eqüidade: LEVI, Giovanni. Reciprocidad mediterránea.

26 AHU. Códice 1952, CD-room 25. Compromisso (acrescentamentos dos capítulos) da Irmandade do Glorioso Mártir São Jorge no Rio de Janeiro (1791).

27 Em 1755, os irmãos já solicitavam recursos à Real fazenda para a reforma da igreja, que segundo os mesmos, encontrava-se em estado de decadência. Rio de Janeiro. Biblioteca Nacional. (BN) Requerimento do Juiz e Irmãos da Irmandade de São Jorge do Rio de Janeiro, em que pedem uma ajuda de custo para as obras da sua Igreja. CA.18755. Ms.544G, rolo 77 . 
contribuições à manutenção e aumento da irmandade é sublinhada por diversos agentes, assim como o reconhecimento da presença de escravos na agremiação. Ao compromisso original, em 1791, se acrescentam nove capítulos e são criados dez específicos dos tanoeiros: "para a economia particular do seu ofício, em utilidade do seu ofício, em utilidade do Público e do mesmo Ofício de comum acordo com os Suplicantes (...) para o seu particular Governo". ${ }^{28}$ Nesta passagem encaminhada para aprovação,operase com uma concepção de economia como administração, governo da casa - seja esta a corporação ou a loja. ${ }^{29}$ A economia não constituía um domínio autônomo da vida humana. E a julgar pelo regulamento da corporação dos tanoeiros, o pertencimento à irmandade implica em benefício particular, dos oficiais de tanoaria, e do público.

No compromisso dos tanoeiros, agremiados na irmandade de São Jorge a partir de fins do século XVIII, havia um reforço da estrutura corporativa da sociedade e da exclusão social. A primeira questão é perceptível no vínculo compulsório entre os tanoeiros da cidade à irmandade e nas diversas regras atinentes ao seu ofício, que incluem os procedimentos para exame, manutenção de lojas, eleição de juízes de ofício e a participação em cerimônias religiosas, coisas para nós díspares. Ao longo do compromisso repete-se a expressão, "para se evitar o prejuízo da Irmandade e do Público", ou seja, para o benefício comum. No capítulo referente ao ingresso, em que se especificam os procedimentos para adquirir a carta de exame, fica indicado que não se admitem "homem pardo ou preto sendo cativo", reforçando a exclusão por critérios de limpeza de sangue e por status social, que reaparecia no compromisso geral de 1791. ${ }^{30}$ No entanto, temos informações sobre a presença daqueles homens na irmandade de

28 Compromisso (acrescentamentos dos capítulos) da Irmandade do Glorioso Mártir São Jorge no Rio de Janeiro (1791). Apud: AHU, Códice 1952, CD-room 25

29 Encontrei vários documentos em que as lojas dos ofícios são referidas como 'casas', ou seja, em que os termos são sinônimos. Rio de Janeiro. Arquivo Geral da Cidade. (AGCRJ) Códice 44-1-24. Latoeiros e funileiros, Ofícios e juízes de ofícios de latoeiros e funileiros. 1807-1822, f.8-9, 11. Eventualmente, encontra-se a especificação "casa com oficina de latoeiro" ou "casa onde exercita suas funções". Nestes documentos, eram casas de latoeiros, em que o estabelecimento comportava residência e oficina. No entanto, o uso do termo 'casa' deveria ser genérico, haja visto que a dupla finalidade destes estabelecimentos era comum nas sociedades de Antigo Regime. ELIAS, Norbert. A Sociedade de Corte. Rio de Janeiro:Zahar, 2001. Inclusive isso ocorreu no Rio de Janeiro até inícios do século XIX. Para uma reflexão sobre economia na Época Moderna, vale uma consulta ao trabalho de CLAVERO, Barlolomé. Antidora: Antropologia catolica da economia moderna. Milan: Giuffrè Editore, 1991, que aponta a inexistência da mesma como um domínio autônomo. No lugar de economia, oiconomia. Segundo este historiador do Direito, a sociedade européia do início da Época Moderna, estava marcada por relações antidorais, ou seja, uma forma de comunicação, de intercurso social que não mais existe e que adviria sobretudo da teologia (cultura católica), tributária da noção de graça. A partir da análise de uma antropologia religiosa - principalmente teólogos dos séculos XVI e XVII - define antidora como um presente em remuneração a algum benefício. E, concebe a economia, cujo primeiro âmbito é a família, circunscrita à esfera de administração familiar. Para Clavero, família pode incluir grupos amplos, como comunidades religiosas. Quanto ao significado que assinalei no corpo do texto para economia, também vale consultar o verbete 'economica'. BLUTEAU, Raphael. Vocabulario portuguez e latino (1711). Rio de Janeiro: UERJ, 2000, que define o termo da seguinte maneira: "Economica, ou Economia. Deriva-se do grego Oicos, Casa \& do verbo Nemei, Reger, Governar, etc. E econômica é a que ensina o governo, \& regimento particular da casa, família, mulher, criados, \& administração da Fazenda."

30 Ver compromisso dos tanoeiros e de São Jorge (caps. 3 e 10). AHU. Códice 1952, CD-room 25, Compromisso (acrescentamentos dos capítulos) da Irmandade do Glorioso Mártir São Jorge no Rio de Janeiro (1791). 
São Jorge, com importantes funções nas lojas do Rio de Janeiro de 1792. Havia 101 oficiais examinados com lojas abertas na cidade, com escravos e forros na condição de juízes: entre os barbeiros e sangradores, a maioria era de escravos, um total de seis em oito (75\%), cujos senhores eram identificados; o único funileiro identificado sustenta a loja aberta com o auxílio de "um oficial mulato que tem". Entre os oito marceneiros citados, dois (25 \%) eram "mulatos forros". ${ }^{31}$

É interessante fazer referência ao caso de Francisco do Vale Viana, ${ }^{32}$ testamenteiro de José Soares de Magalhães, que administrava uma loja de latoeiro na rua dos Latoeiros (atual Gonçalves Dias) no Rio de Janeiro. Após o falecimento do último, Francisco é acusado pelo juiz, escrivão do ofício e por outros cinco latoeiros de administrar a loja, que era das maiores no ramo, por cerca de um ano. ${ }^{33}$ Nesta, havia oficiais livres e escravos examinados e, após a morte do proprietário, um administrador branco nomeado pelo senado da câmara. Fabricava estribos, ferros de engomar, campainhas de mesa, cocos de cobre, candeeiros do Reino, panelas de cobre e outras miudezas. Em outras lojas do mesmo ofício no Rio, faziamse tachos, chocolateiras e palmatórias ${ }^{34} \mathrm{O}$ caso vem a nós por intermédio dos autos, em que se destacam a duração, a quantidade de registros e as motivações do processo. Este transcorre entre, pelo menos, 1783 e 1789, sendo transferido aos herdeiros do réu, a mulher e os filhos, e é suspenso por falta de procuradores dos réus que sustentassem o litígio. O processo aponta para a ameaça representada por este liberto que concorre no mercado local, contra os interesses dos juízes e alguns oficiais de latoeiro. Os argumentos apresentados pela acusação focalizam as regras do ofício - o réu não é nem oficial do ramo, nem examinado e trabalha com licença de ferreiro adquirida fora da cidade contra as posturas do Senado - mas vem a calhar a um testamenteiro liberto. Segundo João Gomes de Campos, um dos procuradores do réu, os autores do processo "caluniosos e movidos de um puro ódio, emulação e vingança, querem confundir a administração com a Regência". No seu argumento, que sublinha as razões do conflito, Francisco regeria a loja, pois representava juridicamente o proprietário falecido, e, se a administrava, seria apenas em termos de a "vigiar e zelar", garantindo que os escravos "não andassem vadios", "trabalhassem com

31 Rio de Janeiro. Biblioteca Nacional (BN). Manuscritos 7,4,4 Artes mecânicas: Relação geral de todos os juizes dos diferentes ofícios mecânicos existentes nesta Cidade, ate o principio do presente ano de 1792.

32 AGCRJ. Códice 45-4-46 latoeiros. Autos do juiz e escrivão deste ofício contra Francisco do Vale Viana (1783).

33 Segundo Francisco do Vale Viana, a loja era "das maiores do dado ofício e se compõe de vários oficiais de pichileiro e funileiro". AGCRJ. Códice 45-4-46 latoeiros, f.10. Autos do juiz e escrivão deste ofício contra Francisco do Vale Viana (1783).

34 AGCRJ. Códice 45-4-46 latoeiros. Os autos mencionam três lojas: aquela sob a regência do réu, Francisco do Vale Viana, a de propriedade do juiz de latoeiro, José Antônio Pereira da Cruz, que também é acusado de produzir e vender obras de outros ofícios, na qual encontravam-se tachos e chocolateiras e a loja de José Barbosa da Fonseca, fabricante de chapéus de sol, acusado de fabricar e vender palmatórias. Autos do juiz e escrivão deste ofício contra Francisco do Vale Viana (1783). 
cuidado", para que as obras fossem concluídas. No entanto, não consistia a regência no trabalho e nas obras, que ficavam sob o encargo de um mestre examinado e assalariado. Por intermédio das testemunhas de acusação todos latoeiros - e do próprio réu, que no registro do escrivão da câmara se contradiz, Francisco é quem no fim das contas administra a loja. ${ }^{35}$ Ele o faz pelo "governo dos escravos" que ali trabalhavam e sustenta a loja até vendê-la a um dos ex-administradores ou seu testa-de-ferro, em 1783, já que não gozava de permissão pública.

A historiografia tem apontado para a adaptação das irmandades à sociedade escravista e, a julgar pelos dados analisados por Carlos Alberto Medeiros Lima sobre os ofícios artesanais do Rio de Janeiro entre fins do XVIII e início do XIX, os trabalhadores cativos concentravam-se em funções complementares e nichos da produção artesanal, de qualquer forma centrais à interpretação da economia política dos privilégios. A partir de dados sobre os mestres examinados nas suas corporações de ofícios, entre 1793 e 1816 e inventários post-morten entre 1789 e 1817 o autor indica, por exemplo, entre ferreiros, caldeireiros e tanoeiros a presença de cativos, em ordem decrescente. ${ }^{36} \mathrm{Em}$ princípio todos, nesse período, ofícios de São Jorge.

Para se ter uma dimensão comparativa, é importante recorrer à análise de Wilson Rios sobre os oficiais mecânicos de Salvador e Vila Rica. A partir de uma amostragem sobre os pedidos de exames entre 1749-1802, ele conclui que existiam variações regionais na demanda dos ofícios e que a presença de escravos e forros nos ofícios artesanais de Salvador é minoritária, exceto nos ofícios não artesanais, como entre os ofícios que lidavam com sangue ou imundície, considerados como atividades "menos nobres". No entanto, assinala que qualquer comparação é arriscada dadas as diferenças nos registros (ora por naturalidade, ora por status) e no caso de Vila Rica de ainda maior complexidade, pois não há evidências de confrarias exclusivas de ofícios. ${ }^{37}$

35 As testemunhas de acusação são todos latoeiros, moradores da rua dos latoeiros, sendo dois ex-oficiais da loja. As testemunhas de defesa compreendem vários ofícios, com status e naturalidades diversas. Estas demoram a dar o seu testemunho. Pelo registro precário, sabe-se que as testemunhas de defesa não testemunharam tão logo se dispuseram e o réu teve que solicitar dilações para assegurá-las. Vários elementos, incluso outros casos corroboram para a idéia de concorrência representada pelos oficiais forros, no caso, Francisco Viana. AGCRJ. Códice 45-4-46 latoeiros. Autos do juiz e escrivão deste ofício contra Francisco do Vale Viana (1783).

36 LIMA, Carlos Alberto. Pequenos Patriarcas: pequena produção e comércio miúdo, domicílio e aliança na cidade do Rio de Janeiro (1786-1844). Rio de Janeiro: Universidade Federal do Rio de Janeiro, 1997, p.38-40 (História, Tese de Doutorado); MARTINS, Mônica de Souza Nunes. Entre a cruz e o capital: mestres, aprendizes e corporações de ofícios no Rio de Janeiro (1808-1824), p.68-70.

37 RIOS, Wilson de Oliveira. A lei e o estilo. A inserção dos ofícios mecânicos na sociedade colonial, p.121-122. No Rio de Janeiro de 1820, há um registro sobre o exame de um escravo barbeiro que aponta para uma classificação semelhante indicada por Wilson Rios com relação aos barbeiros na Bahia. A permissão para o exame é dada pela falta de oficiais peritos que padece o país e é justificada pelo ofício, "por que as artes de que se trata, tem mais de mecânicas do que de liberais". AGCRJ. Códice 6-1-23. 
Na irmandade de São José - que reunia pedreiros, carpinteiros, marceneiros e canteiros ${ }^{38}$ - como em outras da cidade do Rio de Janeiro, a presença de escravos e forros foi motivo de conflitos e exigiu mudanças. Entre 1807-1831, há várias petições à câmara em que a questão está colocada. Seguem-se quatro casos.

No primeiro, a irmandade de São José encaminha uma representação ao príncipe regente, solicitando que se proíbam as vendas de obras de marcenaria pelas ruas da cidade, acusando os oficiais proprietários de escravos de efetuarem uma concorrência desleal, prejudicial aos lucros da irmandade e ao seu "crédito", ou seja, à qualidade atribuída as suas obras de marcenaria. A petição sugere que seja encaminhada a solução aplicada em benefício dos sapateiros em dois de abril de 1813. ${ }^{39}$ Gostaria de sublinhar que os suplicantes consideram-se merecedores da "mesma atenção" por parte de "Sua Alteza Real como (....) Clemente Pai dos seus Fiéis Vassalos". 40

Em 1815, José Joaquim dos Santos, oficial de marceneiro recorre à câmara para proceder ao seu exame do ofício. Ora, cabia à irmandade especificamente, ao juiz de ofício e ao escrivão - cuidar dos exames para ingresso e pertença ao ofício e à câmara confirmá-lo mediante a carta de exame ou bilhete. Segundo o marceneiro, o juiz de ofício, João Luis de Melo, negava-se a examiná-lo alegando a necessidade de uma taxa de entrada para a irmandade e o fato de ter o suplicante "acidente de cor". No entanto, ele já pertencia à irmandade...

Cinco anos depois, Francisco Álvares Negreiro, natural de Mariana, onde foi examinado e aprovado como oficial de carpinteiro, solicita que sua carta seja registrada na cidade do Rio para que possa exercer o seu ofício em obras públicas. Por ser "pobre", solicita ainda que seja eximido dos custos. A questão é resolvida rapidamente, entre janeiro e fevereiro de 1820. O juiz de ofício de carpinteiro certifica que Francisco é um "bom e hábil oficial", "conformando-se em todo o merecimento que se deve a este

38 CAVALCANTI, Nireu. O Rio de Janeiro setecentista. Rio de Janeiro: Jorge Zahar Editor, 2004; MARTINS, Monica de Souza Nunes. Entre a cruz e o capital: mestres, aprendizes e corporações de ofícios no Rio de Janeiro (18081824). Canteiro era aquele que lavrava a pedra de cantaria, escultor de pedra. Sobre a inclusão na Irmandade de São José. AGCRJ. Códice 46-2-22, f.32. Marceneiros e carpinteiros (1812-1831).

39 Em dois de abril de 1813, a câmara proíbe a venda de calçados pelas ruas, uma demanda da irmandade de São Crispim e Crispiniano encaminhada por intermédio do juiz e escrivão e demais oficiais de sapateiros. A decisão resulta de um conflito entre os oficiais agremiados na irmandade, a câmara e os oficiais, que não pertenciam àquela. A vitória da irmandade ocorre após um conflito, que perdura desde, pelo menos, os anos sessenta do século XVIII. Entretanto, é uma vitória relativa, pois a demanda pela proibição continua após aquela data. De qualquer forma, é importante informar que a irmandade procura proteger a corporação contra a concorrência, representada principalmente pelos pardos e pretos cativos ou seus proprietários não agremiados à irmandade. 0 Aviso Régio de 1813 foi publicado e, pelos registros, recupera outras decisões favoráveis aos oficiais de sapateiros agremiados na irmandade no século XVIII. E que já haviam servido de modelo para outros ofícios na cidade. AGCRJ, Códice 50-1-11, Sapateiros, Autos (1771-1772); Códice 50-1-12. Sapateiros, documentos sobre ofícios de juízes e escrivães de sapateiros (1813-1827)

40 AGCRJ. Códice 46-2-22, f.3. 
Vassalo que deve ser atendido, bem que a qualidade seja pardo". ${ }^{41}$ Mais uma vez, a câmara é tribunal de primeira instância, que registra casos ligeiros e conflitos duradouros. Neste caso, o candidato é atendido a despeito de sua condição de pardo, pois, pelo registro do juiz de ofício, sua habilidade é duplamente reconhecida: por um documento do regedor de justiça e por informações colhidas junto ao arquiteto da rainha, Manoel da Costa.

O quarto caso, ocorrido cerca de 1820, pode ter relação com o segundo. Mas, provavelmente, aponta para a recorrência de pedidos de exame por mulatos e pardos ao juiz de ofício de marceneiro. Este solicita à irmandade de São José que se posicione sobre o assunto. ${ }^{42} \mathrm{~A}$ resposta do secretário da irmandade cita o capítulo 28 do seu compromisso, ${ }^{43} \mathrm{em}$ que ficara estabelecido que "todo o irmão em que se achar raça de Mulato, Mouro ou Judeu e todas as vezes que em qualquer tempo, com clareza de saber, será lançado da Irmandade fora sem remissão alguma, e o mesmo se entenderá com suas Mulheres, tendo qualquer das sobreditas faltas". A regra fora confirmada por uma provisão do Desembargo do Paço de 20 de dezembro de 1730 que pressupunha o reconhecimento do ingresso na irmandade para realizar o exame e abrir uma loja e, segundo consta, era praticada no reino do Brasil. Contudo, o juiz de ofício em exercício no ano de 1820 justifica que a irmandade ditada pelas "circunstâncias do País", ou seja, pelas condições de trabalho locais, passa a admitir mulatos. Estes teriam que pagar a entrada de 19.200 réis para o Santo "para ficar remido de servir os Cargos da Irmandade e gozar dos ofícios Divinos; conciliando, por este meio, a inabilidade da pessoa reprovada pelo Compromisso e a suficiência do indivíduo para exercer o ofício".

Com a decisão, em princípios do século XIX,44 adotava-se a solução de um "meio benefício", atribuindo aos mulatos os benefícios e deveres de seu ofício, exceto o acesso aos cargos da irmandade. Nem sempre, "quem tem ofício tem benefício", como já evocava o adágio português, ou ao menos, o benefício integral.

A marca da exclusão por critérios de pureza de sangue fica expressa em várias passagens do mesmo discurso. Por exemplo, ele preconiza àqueles que "aspiram a servir os Cargos da Irmandade para figurarem ombreando

41 AGCRJ. Códice 46-2-22, f.36-39.

42 AGCRJ. Códice 46-2-22. f.15. Os dois termos - mulato e pardo - aparecem na representação do juiz de ofício à irmandade. Nos demais documentos, usam-se somente mulatos.

43 Há indicações sobre um compromisso da irmandade de 1758. No entanto, encontram-se referências a um anterior a esta data, em função de um processo movido pela irmandade contra um marceneiro não oficial, não examinado, que tinha loja com quatro aprendizes. No processo, há consultas realizadas sobre o compromisso na década de 40 do século XVIII AGCRJ. Códice 40-3-91, Autos de execução, Carpinteiros e marceneiros (1759). Ver também AHU. Manuscritos Avulsos do Rio de Janeiro. (MARJ), CD-room 4, Petição do juiz e irmãos da irmandade do Rio de Janeiro (1744) solicitando a adoção do compromisso da irmandade de São José de Lisboa, de 1709.

44 Não sabemos a data exata da decisão. No documento de 1820, registra-se que "Este meio [foi] adotado e observado constantemente há tantos anos passou a costume com privilégio de prescrição". AGCRJ. Códice 46-2-12, f.17; MARTINS, Monica de Souza Nunes. Entre a cruz e o capital: mestres, aprendizes e corporações de ofícios no Rio de Janeiro (1808-1824), p.63-71, 90. 
com os de superior qualidade, é digna de repulsa sua ousadia; busquem alistar-se na irmandade que lhes é própria". Em termos mais gerais, o juiz formula que a decisão vem contribuindo para "conservar o equilíbrio tão necessário entre as diferentes hierarquias que compõem a ordem social; sem ele se reduziria à desordem e quebraria a Cadeia que prende esta grande Máquina".

A despeito do caráter disperso das informações sobre a irmandade de São José, tomadas a partir dos casos localizados na documentação da câmara, evidencia-se a recorrência do critério da cor no mundo dos ofícios. A singularidade do último caso narrado está na clareza cristalina com que o juiz de ofício elabora um parecer - subscrito pelo conjunto da irmandade - em que sugere a conservação da ordem do Antigo Regime, através do emprego das noções de hierarquia e honra. Neste ponto, é interessante demarcar que o juiz de ofício clama a câmara por um castigo aos mulatos que ousam afrontar a sua honra, de juiz e empregado público.

\section{O juiz dos ofícios e a Casa dos Vinte e Quatro}

A irmandade de São Jorge era uma instituição hierárquica dirigida por uma mesa, composta por um juiz, escrivão, tesoureiro, procurador e doze irmãos eleitos anualmente no domingo anterior ao dia do Santo (23 de abril). ${ }^{45}$ Como na maioria das irmandades, os cargos de juiz e escrivão dos ofícios eram de grande importância. Entretanto quero pôr em evidência o juiz dos ofícios e o momento da eleição, comparando situações ocorridas nas irmandades de São Jorge e São José.

Ao analisar os compromissos de São Jorge $(1757,1791)$ e documentos anexos fica evidente a centralidade do juiz de ofício. É ele o responsável pelo culto do santo, função indissociável dos "negócios árduos", para as quais devia convocar a mesa. O juiz (com o auxílio do escrivão) controlava o ingresso e a manutenção dos membros da instituição e ainda intermediava as relações entre a irmandade e a câmara, adquirindo privilégios que o distinguiam numa sociedade hierárquica e escravista. Nessa irmandade de ofícios cabia-lhe atestar pureza de sangue ou ausência de mácula dos pretendentes à corporação e avaliar periodicamente os ofícios em exercício. Nas irmandades "de pretos", cabia-lhe inclusive julgar e punir no lugar dos senhores, tornando-o intermediário entre as autoridades e a massa escrava. ${ }^{46}$

A eleição era um momento-chave na vida das irmandades. Na de São Jorge, era momento de escolha do juiz dos ofícios e dos demais membros

45 AHU. MARJ. Códice 1949, CD-room 25. Compromisso da Irmandade do Glorioso São Jorge no Rio de Janeiro (1757).

46 SILVEIRA, Renato da. Escravidão e invenção da liberdade. São Paulo: Brasiliense, 1988, p.168-169. 
da mesa, de emergência dos conflitos internos e externos, quando a autonomia dos ofícios e a aliança entre a irmandade e a câmara são colocadas em questão.

No compromisso de São Jorge (1757) evidencia-se a preocupação dos irmãos em garantir a ordem da eleição e evitar as perturbações. O assunto é tão repetido que, pode-se supor, a desordem já se fazia presente. Nesse sentido, o trabalho do juiz é também o de lidar com o "irmão perturbador", "fazendo um corpo" com o escrivão, tesoureiro, procurador e os doze irmãos da mesa, ou seja, contribuindo para a unidade da corporação. Nas eleições, o juiz era o único com poder de intervir no voto de um mesário. Segundo o compromisso, o votar era livre, conforme a consciência, mas "quando Ihe pareça que alguns votam com equivocação, ou menos razão poderá propor-lhe o que lhe parecer que é justo para os trazer ao que for" ${ }^{47}$

O seu poder está em mover o irmão equivocado, fazendo uso de persuasão. O regulamento sobrepõe os critérios da "justiça", "razão" e "utilidade" encarnados no juiz, representante da corporação, às "teimas e caprichos impertinentes" dos indivíduos que não se dispõem a mudar de posição. A leitura do capítulo que regulamenta as obrigações dos irmãos da mesa aponta para uma minuciosa tentativa do discurso em controlar o coro de vozes no interior da irmandade. O "irmão perturbador" deveria se subordinar para se reintegrar à corporação. Caso não o fizesse, após algumas advertências, seria expulso, registrando-se sua saída para não ser esquecida pelos agremiados. O que está em jogo é não apenas um ideal de hierarquia que preside o funcionamento destas instituições do Antigo Regime, mas uma concepção corporativa de sociedade, na qual o poder tem por finalidade primeira ou única a realização da justiça. ${ }^{48}$ Também está em jogo o papel do juiz e da mesa na condução do auto-governo da irmandade.

A eleição do juiz era um tema espinhoso, que cabia não apenas aos irmãos da mesa, mas que mobilizava a câmara e outros órgãos. A afirmação é possível, tendo em vista situações desencadeadas pela irmandade de São Jorge, em 1757, pela de São José, em 1744 no Rio de Janeiro e uma ocorrência semelhante na Bahia, entre 1701 e $1706 .{ }^{49}$ Outro fator que permite tal afirmação diz respeito à esperada partilha e articulação de poderes entre o juiz de ofício e a câmara na regulamentação da economia dos ofícios. ${ }^{50}$ Simplificadamente, cabia ao juiz de ofício garantir a prática

47 AHU. MARJ. Códice 1949, CD-room 25, Cap.3 e 8. Compromisso da Irmandade do Glorioso São Jorge no Rio de Janeiro (1757).

48 HESPANHA, António Manuel e XAVIER, Ângela Barreto. A representação da sociedade e do poder. In: MATTOSO, José. (org.) História de Portugal. Lisboa: Estampa, 2006, p.123.

49 RIOS, Wilson de Oliveira. A lei e o estilo, p.142-144.

50 HESPANHA, António Manuel e XAVIER, Ângela Barreto. A representação da sociedade e do poder. 
dos ofícios examinados e a indicação dos transgressores e à câmara, o seu julgamento e punição. ${ }^{51}$

No compromisso de 1757, os irmãos de São Jorge propunham que a eleição do juiz e escrivão fosse realizada pelos próprios irmãos e confirmada pela câmara. Além disso, queriam que o juiz e escrivão fossem sempre um representante dos ferreiros e outro dos serralheiros. Depois de muita discussão, a documentação relativa ao requerimento e confirmação do regulamento indica que a câmara, com o apoio do Conselho Ultramarino, do procurador da Fazenda e do procurador da Coroa, teria conseguido a alteração destas regras. Nos termos do documento de aprovação, subscrito pelos conselheiros, "a eleição de juízes dos ofícios mecânicos toca aos oficiais da câmara. E se não deve a Confraria intrometer". A mensagem clara e repetida no texto reduz a autoridade da irmandade na cidade do Rio, tornando-se condição para a confirmação do compromisso. Mas deixa evidente uma tensão entre a irmandade e a câmara, pois esta nega a autonomia da primeira nesta matéria. Não temos notícias sobre como os juízes fariam uso de sua posição, todavia vale mencionar que no compromisso posterior, de 1791, reafirma-se a proposta dos irmãos.

A situação que emerge na irmandade de São José em 1744 é ainda mais eloqüente. A razão é similar - a faculdade dos irmãos de elegerem os juízos de ofício na Mesa, ainda que por registros indiretos. Essa demanda nos permite auscultar o discurso das partes, reconhecendo que o argumento do "bom governo" e/ou "bom regime" é onipresente. Ou seja, ele é evocado pelos irmãos de São José, vereadores, ouvidor-geral do Rio de Janeiro e pelos membros Conselho Ultramarino ao longo do processo. Ainda que os argumentos de cada um dos agentes sejam interessantes, darei prioridade aos dois pólos da questão: a irmandade e a câmara.

Os irmãos marceneiros e carpinteiros requerem "a graça de prontamente eleger na mesa os Juízes dos ofícios por não haver na dita cidade a mesa dos vinte e quatro, como há nesta Corte sendo somente nesta eleição aprovada [pelo Senado]". 52

A petição da irmandade inclui a adoção do compromisso dos ofícios da bandeira de São José de Lisboa, de 1709, pelos pedreiros, carpinteiros e marceneiros da cidade do Rio e ainda a manutenção do Senado como "juiz privativo" dos ofícios. Quero sublinhar apossibilidade de negociaçãoque neste momento se coloca, pois nesses quesitos há uma coincidência de propósitos entre os oficiais da irmandade e as autoridades envolvidas na questão. No requerimento dos irmãos, repete-se uma direção "para o

51 Ver nota 22, em que explico o procedimento para adquirir a carta de exame, que envolvia as irmandades e a câmara. E, AHU. MARJ. CD-room 4. Compromissos de São Jorge $(1757,1791)$. Capítulos das obrigações pertencentes aos Ofícios da Bandeira do Patriarcha S. Joseph § VIII de Lisboa, 1709 que seriam aplicados no Rio de Janeiro a partir de 1744

52 AHU. MARJ, CD-room 4. 
bom governo, aumento e veneração de sua Igreja" e irmandade. Pouco depois, registrava o ouvidor-geral, a irmandade de Lisboa "é uma das que se elege com tal disposição não só se aumenta continuamente, mas promete eterna duração". A desta cidade "deve militar a mesma jurisdisposição (sic)" tomando as práticas jurídico-políticas do reino como modelo para o a sociedade colonial.

De acordo com os procedimentos atualizados pelo Conselho Ultramarino, foram ouvidos os oficiais dos mesteres (oficiais mecânicos) e os da câmara. ${ }^{53}$ No despacho da câmara, os últimos são contrários à autonomia dos oficiais mecânicos na escolha dos juízes e o afirmam com virulência. A riqueza dos argumentos, das acusações empregadas pelos vereadores é grande se comparada à resposta dos artífices, mas esta passa pelo filtro dos conselhos e será voz vencida. Infelizmente, não temos acesso ao conjunto da resposta, pois o documento sofreu a ação do tempo.

O documento da câmara argumenta que "desde a fundação desta cidade, se pratica por estilo Inalterável" que os oficiais votem nos juízes e estes eram confirmados pelo Senado. Mais à frente, indica e enumera as funções dos juízes e escrivães dos ofícios: cuidados das irmandades, das festividades de seus oragos e, no Senado, das avaliações das obras da cidade, do procedimento de inventários, e mais atos jurídicos ordenados para a boa administração da Justiça da irmandade. O eixo do argumento estava na idéia de jurisdição (auto-governo, especialização), mas também na articulação entre juizes de ofício e Senado, ameaçada pelos oficiais. ${ }^{54}$ Nesse sentido, diferencia os poderes do juiz de fora do dos juízos dos ofícios, opondo a prática, o costume e a forma ordinária à excessiva liberdade e ao despotismo dos ofícios, conforme termos da época. Esta é apenas uma das ocasiões em que os vereadores identificam a sua jurisdição à da República, como governo dos cidadãos que tem como referência o bem comum. Vejamos nos seus próprios termos:

Será cousa estranha e prejudicial à utilidade pública, que os tais oficiais exercessem a Liberdade de fazer esta Casta de Juiz a seu arbítrio independentes da forma judicial, que se pratica nesta ma (sic) terra Com tão longo uso costume sem nenhuma Utilidade do bem comum mais do que a vaidade do Autor deste requerimento fazendo capricho de que as eleições de que se trata tenham diversidade da forma ordinária só afim de haver a Liberdade pretendida contra a Jurisdição deste Senado com despótico procedimento destes ofícios (...).

53 Para os significados de mester, ofício e oficial no século XVIII, a partir do qual empregam-se os termos no corpo do texto: BLUTEAU, Raphael. Vocabulario portuguez e latino.

54 Para uma definição precisa do paradigma corporativo de sociedade e poder em Portugal: HESPANHA, António Manuel e XAVIER, Ângela Barreto. A representação da sociedade e do poder. Para as definições dos conceitos de "jurisdição" e "graça" e discussão sobre sua centralidade no interior do paradigma corporativo atualizado pela segunda escolástica consultei: HESPANHA, António Manuel. Porque é que foi "portuguesa" a expansão portuguesa? ou O revisionismo nos trópicos, p.44-48. 
Que não se suprima o artigo cujo é costume estabelecido em utilidade da boa administração da Justiça e regimedesta Republica. ${ }^{55}$

Vale observar que os vereadores fazem uso da idéia de bem comum - noção freqüente no mundo dos ofícios desde a Idade Média, particularmente entre os séculos XI e XIII quando se identifica um processo de conceptualização de um mundo novo associado à mudanças de ordem econômica e social. Neste período, como analisou Le Goff, há uma tomada de consciência por parte dos mesteres e a noção de bem comum torna-se "a pedra de toque da utilidade e legitimidade de todas as profissões". Para levar a efeito a análise, o historiador articula três pontos: uma modificação da estrutura social, evidente na diversificação ocorrida, sobretudo nos meios urbanos; a evolução da confissão, que aponta para a subjetivação da religião; uma mudança de atitude perante o trabalho, que, simplificadamente, passa da noção de penitência para um meio de alcançar a salvação. Para efeito da reflexão nas sociedades do Antigo Regime, é importante registrar que no medievo as atividades realizadas pelos mesteres passariam a ser legitimadas, desde que associadas ao útil e ao necessário à cidade. O leque das profissões lícitas foi ampliado, mantendo-se uma hierarquia entre elas e atrelando-as ao bem comum. ${ }^{56}$

Naquele processo, a igreja e as autoridades locais reconhecem a existência das corporações, submetendo o "governo econômico" dos ofícios à administração da cidade. Consequentemente, "as corporações ou os ofícios submetidos a regras [de monopólio] transformavam-se em instrumentos públicos e oficiais de fiscalização - da formação da mão-deobra, da qualidade e do preço dos produtos, do cumprimento das regras ou exigências para o exercício da profissão". Na expressão feliz de Henri Pirenne, elas tornaram-se "fiscais de si mesmas e do bem comum". ${ }^{57} \mathrm{O}$ preço do reconhecimento público foi a perda de controle da gestão do mercado, mas elas conservam a sua autonomia interna e ainda fornecem um enquadramento social aos artesãos.

Para que possamos melhor interpretar o conflito entre a irmandade de São José e a câmara na cidade do Rio de Janeiro, considerando a recorrência da querela entre os oficiais mecânicos e a câmara sobre a autonomia dos primeiros na eleição dos juízes, vale recorrer à história dos ofícios em Portugal. Segundo Rios, o defeito mecânico é uma classificação advinda da natureza manual das ocupações, sobre a qual incidia uma remuneração, que era aplicada aos oficiais mecânicos e mercadores. Para o autor, os oficiais mecânicos constituíam não só uma categoria profissional, mas

55 AHU. MARJ, CD-room 4

56 LE GOFF, Jacques. Para um novo conceito de Idade Média: tempo, trabalho e cultura no ocidente, p.151-167.

57 RIOS, Wilson de Oliveira. A lei e o estilo, p.26-27. 
uma identidade social marcada por aquele estigma social negativo, que se contrapunha à honra da nobreza e aos privilégios jurídicos associados a este grupo. Num longo movimento pela história, sua análise demonstra que os oficiais mecânicos têm acesso em determinados momentos a distinções e privilégios que não resultam da descaracterização do defeito mecânico. Muito pelo contrário, o acesso a eles está relacionado ao caráter atribuído às funções de representação exercidas na cidade.

Nessa direção, Rios recupera a história dos ofícios desde o reinado de dom João II, quando, em resposta a uma solicitação da câmara de Lisboa nas Cortes Gerais de 1481-1482 pela obrigatoriedade do exame dos ofícios. A Coroa não o institui, mas determina que todos os ofícios elaborem regimentos próprios e que as câmaras escolham dois juízes para fiscalizar o cumprimento dessas regras. Com o tempo, o juiz de ofício adquiria prestígio social e dignidade profissional, revelados na convocação para pareceres de obras públicas, ocupação de funções fixas relacionadas aos ofícios e participação nas cerimônias públicas. Contudo, estes não significaram acesso à honra de nobreza. Para Rios, o momento de maior inflexão ocorreria na dinastia de Avis, quando o soberano garantiu aos oficiais mecânicos o privilégio de participarem da câmara, na deliberação dos assuntos da cidade, o que daria origem à Casa dos Vinte Quatro. ${ }^{58}$

A passagem que transcrevi dos vereadores do Rio de Janeiro contra a autonomia da irmandade na eleição do juiz sugere uma re-inscrição do autor do requerimento - o representante dos ofícios de carpinteiro e marceneiro - na ordem estamental. Na república, cabiam aos ofícios os papéis associados pelo uso e costume ao bem comum.

Por intermédio das autoridades coloniais, tem-se acesso à voz dos ofícios, que queriam poder eleger seus próprios juízes e um dos argumentos é a inexistência da chamada Casa dos Vinte e Quatro na cidade do Rio de Janeiro.

A Casa dos Vinte e Quatro tem sido descrita como uma forma de representação dos ofícios baseada no sistema de corporações. Os líderes dos comerciantes e artesãos elegiam anualmente, entre os membros de sua corporação, 12 ou 24 representantes. Entre estes eram escolhidos quatro que se tornariam os procuradores dos mesteres (procuradores dos ofícios), com direito a participar das sessões de vereança. ${ }^{59}$ A instituição é

58 RIOS, Wilson de Oliveira. A lei e o estilo, p.78.

59 FAZENDA, Vieira. As bandeiras dos ofícios; LANGHANS, Franz- Paul. A Casa dos vinte e quatro; BERNSTEIN, Harry. O juiz do povo de Lisboa e a Independência do Brasil: 1750-1822, ensaio sobre o populismo luso-brasileiro. In: $\mathrm{KEITH}$, Henry H e EDWARDS, S. F. (orgs.) Conflito e continuidade na sociedade brasileira - ensaios. Rio de Janeiro: Civilização Brasileira, 1970, p.226-265; GONÇALVES, Lopes. As corporações e as bandeiras de ofícios; BOXER, Charles H. O império marítimo português. 1415-1825; BICALHO, Maria Fernanda. O que significava ser cidadão nos tempos coloniais?; RIOS, Wilson de Oliveira. A lei e o estilo. 
criada em Lisboa no reinado dom João I, em 1422. ${ }^{60}$ Posteriormente, em outras cidades do reino, como Santarém, Guimarães, Coimbra, Évora e no Porto. Parece interessante a hipótese em que se reconhece a perspectiva do Mestre de Avis, depois dom João I, em "dar cunho político ao velho costume de em certas ocasiões os homens dos mesteres serem chamados a tomar parte nas deliberações". A partir da interpretação da carta régia que Ihe deu origem, pode-se dizer que a decisão constituía um benefício pelo engajamento dos oficiais mecânicos no movimento que levara ao poder a dinastia de Avis. "Como em todas as concessões de privilégios, os que beneficiavam a Casa dos Vinte e Quatro também envolveram relações de gratidão, lealdade e obediência". ${ }^{61}$

Os eleitos para a Casa dos Vinte e Quatro seriam os homens bons dos mesteres, seus representantes, com capacidade de intervenção no município, ${ }^{62}$ que adquiriram diversos privilégios entre os séculos XV e XVII, sempre sujeitos à revogação. ${ }^{63}$

Ainda hoje muito se ignora a respeito do funcionamento dessa instituição, que em Portugal perdurou até 1834. Como se não bastassem as dúvidas sobre seu surgimento, finalidades, é incerto que fossem os juízes dos ofícios os eleitos da Casa e aqueles a escolher os procuradores dos ofícios e o juiz do povo. ${ }^{64}$ De acordo com a legislação, a presidência da casa seria instituída no século $\mathrm{XV}$, denominando-se o cargo como juiz ou juiz dos Vinte e Quatro. No século XVII, o termo juiz do povo se impôs na documentação. Para integrar a casa, era necessário ser alfabetizado, examinado, embandeirado e possuir tenda ou loja própria. Segundo Rios, ao longo do tempo, as exigências tornaram-se mais seletivas, pressupondo a lealdade em troca dos benefícios da nobreza e, contraditoriamente, o defeito mecânico como cláusula de barreira. ${ }^{65}$

Desde o início do século XX, a historiografia debate sobre a sua existência na América portuguesa, fazendo referência sobretudo à experiência dos ofícios na Bahia, entre 1641 e $1713 .{ }^{66}$ Durante este período, os oficiais

60 A data indicada para a criação da Casa dos Vinte e Quatro varia entre os estudiosos. Tomei como referência os trabalhos Franz-Paul Langhans e Wilson Rios, que a datam pela carta régia de 1/4/1422. No entanto, há quem a mencione já em 1383, a partir da crônica de Fernão Lopes, como GONÇALVES, Lopes. As Corporações e as Bandeiras de Ofícios, p.178.

61 RIOS, Wilson de Oliveira. A lei e o estilo, p.81.

62 GONÇALVES, Lopes. As corporações e as bandeiras de ofícios, p.179.

63 RIOS, Wilson de Oliveira. A lei e o estilo, p.78-81.

64 FAZENDA, Vieira. As bandeiras dos ofícios; BERNSTEIN, Harry. O juiz do povo de Lisboa e a Independência do Brasil: 1750-1822, ensaio sobre o populismo luso-brasileiro.

65 LANGHANS, Franz- Paul. A Casa dos vinte e quatro; RIOS, Wilson de Oliveira. A lei e o estilo, p.25.

66 BOXER, Charles H. Portuguese society in the tropics. Madison and Milwaukee: University of Wisconsin Press, 1965; FLEXOR, Maria Helena Ochi. Oficiais mecânicos na cidade de Salvador. Salvador: Prefeitura Municipal de Salvador, 1974; SCHWARTZ, Stuart. Ceremonies of public authority in a colonial capital. The king's processions and the hierarquies of power in the seventeenth century Salvador. Anais de História de Além-Mar, v.5, p.7-26, 2004. Vale consultar a explicação apresentada por Rios para a extinção do cargo de juiz do povo em Salvador, que dá ênfase ao papel ativo dos juízes no mercado de abastecimento local ao longo da existência do cargo. Os mesteres e, em particular, o juiz do povo atuava sobre as formas dos contratos, a qualidade, os preços, a distribuição e os tributos sobre os gêneros. Estava atento ao povo miúdo, o que gerou situações de conflito e acomodação com os 
mecânicos tiveram representação direta na câmara de Salvador em questões relativas ao bem público, ou seja, em assuntos da cidade e da vida dos ofícios. Ela era exercida pelo juiz do povo e por procuradores dos ofícios, que tinham voz e voto, mas que eram cerceados pelos homens bons, os cidadãos do lugar. No Rio de Janeiro, há notícias de que os oficiais mecânicos "eram ouvidos pelo Senado" em 1624, 1661 e 1736 por meio dos seus procuradores mas à diferença de Salvador inexistia o Juiz do Povo. Tiveram participação intermitente, com representação corporativa que ainda merece investigação. ${ }^{67}$

Acredito que possamos nos deslocar daquela questão (se existia ou não), quando se considera que a Casa dos Vinte e Quatro operava como um modelo de representação política ${ }^{68}$ que fazia efeito em determinados contextos regionais e que ameaçava o equilíbrio dos poderes do Antigo Regime, como era o caso do Rio de Janeiro do século XVIII. A Casa dos Vinte e Quatro, mesmo no reino, a julgar pela sua longa duração e variadas normas que a regulavam, não tornaria possível uma ação e uma intervenção dos artífices na municipalidade na defesa dos seus interesses como sonham os historiadores da atualidade. Aliás, o trabalho de Langhans, ainda hoje o estudo mais sistemático sobre a organização dos oficiais mecânicos em Portugal, reconhece que o foco na "orgânica e na atividade das passadas representações populares" era uma questão de sua pesquisa. A idéia era "evidenciar o caráter institucional da antiga organização dos mesteres no duplo aspecto jurídico e político", a partir de variadas fontes da história normativa das comunidades, formando com coletâneas anteriores, uma história das corporações em Portugal. ${ }^{69} \mathrm{O}$ Novo Regimento para Governo da Casa dos vinte e quatro fundado nos Alvarás e resoluções dos algustíssimos Monarquas deste reino de Portugal, ${ }^{70}$ ou seja, um conjunto de leis sistemáticas para a organização dos oficiais mecânicos surgiriam na passagem do século XVIII para o XIX, fruto de um projeto que não deve ter saído do papel.

Na cidade do Rio, o modelo é acionado como argumento, até onde sei, pela irmandade de São José, em 1744, para alcançar a graça de escolher os seus juízes e pela irmandade de São Crispim, em 1817, porque

vereadores. Na sua análise, a extinção do cargo está associada aos motins de 1711, como se explica comumente na historiografia, mas leva em consideração as relações desenvolvidas desde 1641 entre a Coroa, câmara e os mesteres. Também, a memória dos vereadores reconstruída em 1756 dos eventos de 1711, em que se associa o juiz do povo aos motins. Ainda assim, reconhece que na câmara os vereadores ficaram divididos com relação à decisão de extinguir o cargo de juiz do povo. RIOS, Wilson de Oliveira. A lei e o estilo, p.128-139.

67 SANTOS, Beatriz Catão Cruz. The feast of Corpus Christi: artisan crafts and skilled trades in Eitheenth-century.

68 MAGALHÃES, Joaquim Romero. A forte presença dos mesteres. In: MATTOSO, José. (dir.) História de Portugal. Lisboa: Estampa, 1994, v.3, p.311-314.

69 LANGHANS, Franz- Paul. A Casa dos vinte e quatro.

70 Apud: LANGHANS, Franz- Paul. A Casa dos vinte e quatro. 
esperava-se o estabelecimento da Casa dos Vinte e Quatro na cidade. ${ }^{71}$ Mas, provavelmente, como em Portugal, havia ofícios na cidade que não queriam se subordinar àquele tribunal. ${ }^{72}$

Não temos acesso à integra da resposta dos ofícios de pedreiros, carpinteiros, marceneiros. Contudo, pode-se dizer que eles duvidaram se o Rei lhes concederia a graça de eleger na mesa os juízes de ofícios e prometeram não contestar a ordem de Sua Majestade. ${ }^{73}$

\section{Considerações Finais}

A análise dos registros da câmara da cidade do Rio de Janeiro e de alguns documentos avulsos sobre as irmandades de São Jorge, São José e São Crispim e Crispiniano, entre fins do século XVIII e início do século XIX, permite concluir que aos oficiais mecânicos estava vedado o exercício da cidadania, excetuando-se os períodos indicados na Bahia - em que os seus representantes atuavam na câmara sujeitos a restrições - e no Rio de Janeiro. A afirmação considera que o estatuto de cidadão se refere a um conjunto de prerrogativas que estão vinculadas aos cargos da administração local, principalmente da câmara. O cidadão é o homem bom, que se distingue dos demais por uma posição superior garantida pela hereditariedade ou alcançada por mecanismos de enobrecimento. Assim, a definição de cidadão, embora não se confunda com a de nobreza, se aproxima dela. ${ }^{74}$ $O$ cidadão tem como alguns de seus pré-requisitos a pureza de sangue e a inexistência de defeitos mecânicos. Por esta razão, quando o termo cidadão aparece nos códices consultados sobre a vida dos oficiais mecânicos serve para nomear o proprietário do ofício de escrivão da câmara ou o seu substituto, em caso de impedimento. ${ }^{75}$ Nesse ponto, o que a pesquisa acrescenta sobre o tema da cidadania? A partir da leitura dos documentos relativos aos marceneiros, carpinteiros e pedreiros verifica-se a incidência do termo vassalo a conviver com cidadão. Ele parece ser uma referência a mais de fundo hierárquico, que fundamenta aquela sociedade de Antigo Regime. No século XVIII, vassalo era sinônimo de súdito. Antigamente, nos diz Bluteau, era título e muito honoríico. ${ }^{76}$ Segundo Moraes e Silva, "eram os Vassalos

71 MARTINS, Monica de Souza Nunes. Entre a cruz e o capital: mestres, aprendizes e corporações de ofícios no Rio de Janeiro (1808-1824), p.202.

72 GONÇALVES, Lopes. As corporações e as bandeiras de ofícios, p.187; MAGALHÃES, Joaquim Romero.A forte presença dos mesteres, p.313.

73 AHU. MARJ, CD-room 4. Para definição de "graça" e sua centralidade nas concepções jurídico-políticas ver HESPANHA, António Manuel. Porque é que foi "portuguesa" a expansão portuguesa ? ou O revisionismo nos trópicos, p.46-48.

74 BICALHO, Maria Fernanda. O que significava ser cidadão nos tempos coloniais?

75 AGCRJ. Códice 50-1-12, Códice 40-3-93. O cidadão como o proprietário do ofício de escrivão da Câmara e o seu substituto aparecem nos anos de 1770, 1804 e 1813. Outro documento, datado provavelmente de 1827 fará referência aos "cidadãos do Império", com significado dissonante, ao meu ver, assinalando mudanças já efetuadas.

76 BLUTEAU, Raphael. Vocabulario portuguez e latino. 
del-Rei, que dele recebiam terras e contias". "A qualidade de vassalo, que começou a dar-se somente aos grandes a filhos, netos e bisnetos de fidalgos de linhagem se difundiu aos não fidalgos". No século XIX, "ainda que esta denominação como classe privilegiada parece extinta e convir hoje a todos os naturais dos Reinos e Domínios de Portugal, todavia em razão do serviço a cavalo e do que podem fazer quem os mantém, temos alguns restos do direito de vassalagem" atribuídos "aos que possuem grossas quantias, dispostos a servir a pátria". ${ }^{77}$

As definições apresentadas nos dicionários nem tudo resolvem. No entanto, apontam para a transformação do conceito no período investigado uma expansão que permite passar do fidalgo, atributo hereditário, ao natural, incluindo os que tinham capacidade de se armar cavaleiros ou dispor de seus bens para servir a pátria, que, em geral, designava o lugar de origem dentro dos domínios portugueses. ${ }^{78}$ Nas petições de oficiais mecânicos dirigidas à câmara em que o título de vassalo é evocado, aqueles buscam minorar o defeito mecânico pelas relações estabelecidas com o rei. Assim, a partir dos casos mencionados, pode-se dizer que os indivíduos de condição social mecânica inserem-se na comunidade política do Rio de Janeiro do Antigo Regime através da participação em irmandades ou corporações de ofícios, de um cargo (juiz ou escrivão destas instituições) que lhes daria acesso ao jogo com a câmara e/ou aos privilégios concedidos pelo rei.

O carpinteiro "cidadão brasileiro" ou o "bom cidadão pedreiro" só fariam sua aparição mais tarde, no ano de $1831,{ }^{79}$ quando então o termo vinha a adquirir novos significados, passando grosso modo de uma compreensão hierárquica a um entendimento igualitário do conceito de cidadania. Ainda assim, a graça concedida por Sua Alteza real não havia desaparecido do horizonte de expectativas.

No Rio de Janeiro, entre fins do século XVIII e inícios do XIX, as noções de bem comum e limpeza de sangue, como procurei assinalar ao longo do texto, também permaneciam como critérios sociais relevantes, se bem que o primeiro, por vezes, adquire uma conotação muito alargada para atender ao bom governo dos cidadãos do lugar.

77 MORAES E SILVA, Antonio de. Dicionário da Língua Portuguesa. Lisboa: Tipografia Lacerdina, 1813. Contia é uma certa porção de generosidade dada pelo rei a um ilustre, que se sacrificava pelo rei em vida ou fazenda.

78 MORAES E SILVA, Antonio de. Dicionário da Língua Portuguesa; BERBEL, Márcia R. Pátria e patriotas em Pernambuco (1817-1822): nação, identidade e vocabulário político. In: JANCSÓ, István. (org.) Brasil: formação do Estado e da Nação. São Paulo/ljuí: Fapesp/Hucitec/Unijuí, 2003.

79 Segue a transcrição do documento, do qual extraí a primeira citação: "diz José Maria da Fruidade, Mestre carpinteiro examinado, morador na Freguesia de Santa Rita desta Cidade, que constando-lhe que esta Mesma câmara tem criar naquela Freguesia um avaliador do dito Ofício e achando-se o Suplicante nas circunstâncias por ser Cidadão Brasileiro, e Mestre examinado por isso. Para Vossas Senhorias sejam servidos deferir ao Suplicante de cuja Graça." AGCRJ. Códice 46-2-22. No segundo, o pedreiro Thomé Matheus descreve sua experiência de mestre em diversas obras públicas realizadas na cidade ao longo de 22 anos e assegura ter jurado a constituição. Então, solicita a manutenção de sua posição de mestre nas obras doravante administradas pelo Senado alegando sua perícia e sua condição de "bom cidadão e amigo da pátria". AGCRJ, Códice 46-4-4, classes de ofícios. 